\title{
Automatic Stacking Crane Prototype using Microcontroller Arduino Mega 2560
}

\author{
Sardono Sarwito ${ }^{1}$, Indra Ranu Kusuma ${ }^{2}$, Fajar Andik Cahyono ${ }^{3}$
}

\begin{abstract}
The function of port is important in supporting the transportation system to develop economic, social, and eduaction with seatrading as booster. Crane is device which use to lift or move heavy loads and commonly was used in ports for container loading - unloading process. This research has been create automatic stacking crane prototype with an Arduino Mega 2560 as controller. There is a lack of this design is the incoming voltage to the motor sourced from this microcontroller module is $5 \mathrm{~V}$. In hence, the spindle motor is not optimal. In addition, there are still many input response procedure was not appropriate.
\end{abstract}

Keywords — crane, microcontroller, automatic stacking crane, control.

\section{INTRODUCTION}

$\mathrm{T}_{\mathrm{t}}$ he port is one of the supporting infrastructures for sea-transportation carrying goods and passengers. The function of port is important in supporting the transportation system for the development of an area in the delivery of goods to be distributed to destination [1].

Crane is device which use to lift or move heavy loads and commonly was used in ports for container loading unloading process. Crane has requirement as procedure for container handling. There are cable with hanging load and lift and drop container in planned area [1-4].

The problem which needs to solve is the automatic stacking crane has complex working system. Crane should be having capability to move load for loading unloading container. Therefore, the control system is very necessary [1-4].

In this case, the function of crane can be simulated using prototype. According to microcontroller work principal which can control another device, this research was aimed to create prototype of automatic stacking crane. The prototype has been operate based on actual condition [4]. The primarily ideas related to this research are:

1) How to design prototype of automatic stacking crane with microcontroller?

2) How to create program for simulation of automatic stacking crane? Cross-check several times to eliminate errors, superfluous material and repetition.

\section{METHOD}

\section{A. Identification}

This step should be done to understand several problems that might be occurred while creating prototype of automatic stacking crane. Identification step consists of collect existing condition, procedure

Sardono Sarwito is with Department of Marine Engineering, Institut Teknologi Sepuluh Nopember, Surabaya 60111, Indonesia. E-mail: sarsar@its.ac.id

Indra Ranu Kusuma is with Department of Marine Engineering, Institut Teknologi Sepuluh Nopember, Surabaya 60111, Indonesia. Email: kusuma@its.ac.id

Fajar Andik Cahyono is with Department of Marine Engineering, Institut Teknologi Sepuluh Nopember, Surabaya 60111, Indonesia. planning, and determining control method.

\section{B. Theoretical framework}

This step consists of learning the basic theory using to while research. Books, papers, internets, tutorials, and regulations has been be resources. Moreover, interview with related stakeholders

\section{Collecting Data}

Collecting data should be taken to get information about systems and work procedures of crane. The data has been be used while creating prototype and simulations.

\section{Data Analysis}

Data analysis is step to process data itre collected. In this step, it has been be planned and designed devices relating to automatic stacking crane system process. There are several devices which used in create prototype and simulation:

1. DC Motor (geared), as trolley, hoist, and grip prime-mover.

2. Mini Servo Motor, as container grip.

3. Sensor reed switch, sensor rotary encoder, limit switch as mover condition detector.

4. Adruino Mega (microcontroller module), with consideration amount pin I/O.

5. Driver motor, as controller DC motor geared.

6. Keypad $4 \times 4$ and LCD as human machine interface which consist of screen and control order.

\section{RESULTS AND DISCUSSION}

\section{A. Mechanical Design Stage}

At the design stage, it has been consist of mechanical design according to actual work. It has been easier to assemble and monitoring of potential failure on device, because work order would be taken based on what had been planned previously.

In the process of prototype construction is primarily mechanical design and program. Mechanical Design among others includes:

1) Making prototype construction crane.

2) Design trolley

3) The design of the hoist and gripper

4) Design box container 
For designing program, device which needed are:

\section{A.1. Program on Arduino Mega 2560}

During creating prototype, it has been use aluminum in. The consideration of using aluminum is caused the material capable to solve short circuit and good enough for supporting the mechanical systems that has been be made later. The construction of prototype is describe in Figure 1 :

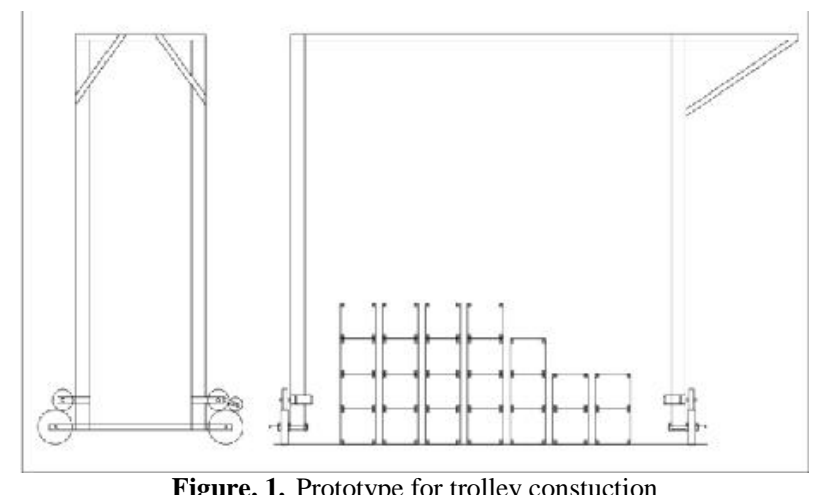

Figure. 1. Prototype for trolley constuction

\section{A.2. Trolley Design}

Trolleys are used for the movement vertically to the device serves as the removal of container from the terminal to the truck or vice versa, or it could be to transfer the location of containers within the terminal itself. The Trolley construction is shown in figure 2:

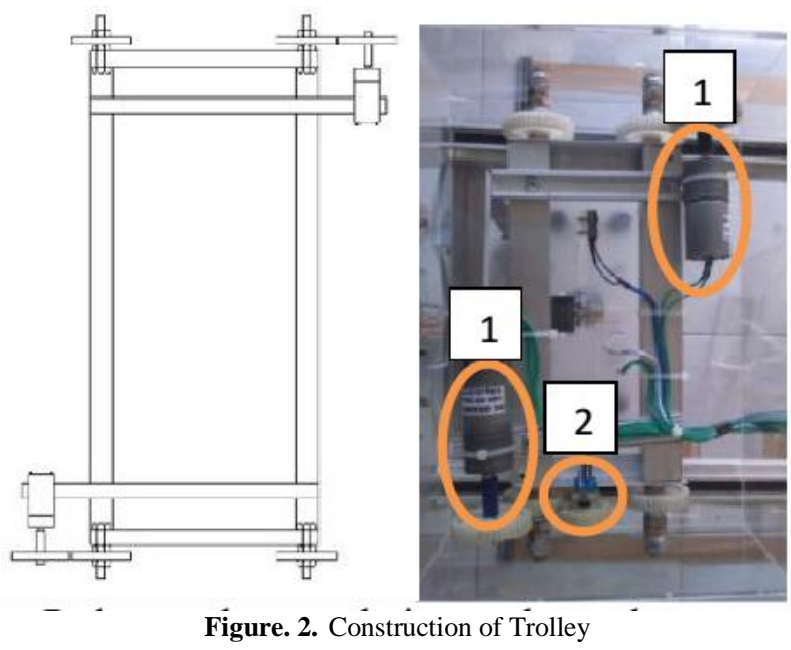

For design, components and specifications of hoist equipment include:

1. Motor DC geared ratio 1:21 12V 38rpm;

$8,6 \mathrm{~kg} / \mathrm{cm} @ 12 \mathrm{~V}$

2. Sensor rotay encoder

\section{A.3. Hoist and Gripper Design}

Hoist is used to process the move up and drop of container. The gripper is used to clamp or locking container in loading unloading process. Hoist and gripper is designed such that it is expected to operate in accordance with the actual work.
The specification of hoist and gripper are:
a. Motor DC geared ratio of 1: $22012 \mathrm{~V} 38 \mathrm{rpm}$ torque of $8,6 \mathrm{~kg} / \mathrm{cm} @ 12 \mathrm{~V}$
b. Motor mini servo
c. Limit switch
d. Sensor reed switch

For move up and drop process, the gripper is driven by DC Motor geared which connected with wire through roller and gripper. When crane drop container, gripper detector has been activate (on/off) if reach their limit switch. When crane move up container, sensor reed switch has been activate if gripper reach top limit. The construction of hoist crane is shown in Figure 3. 


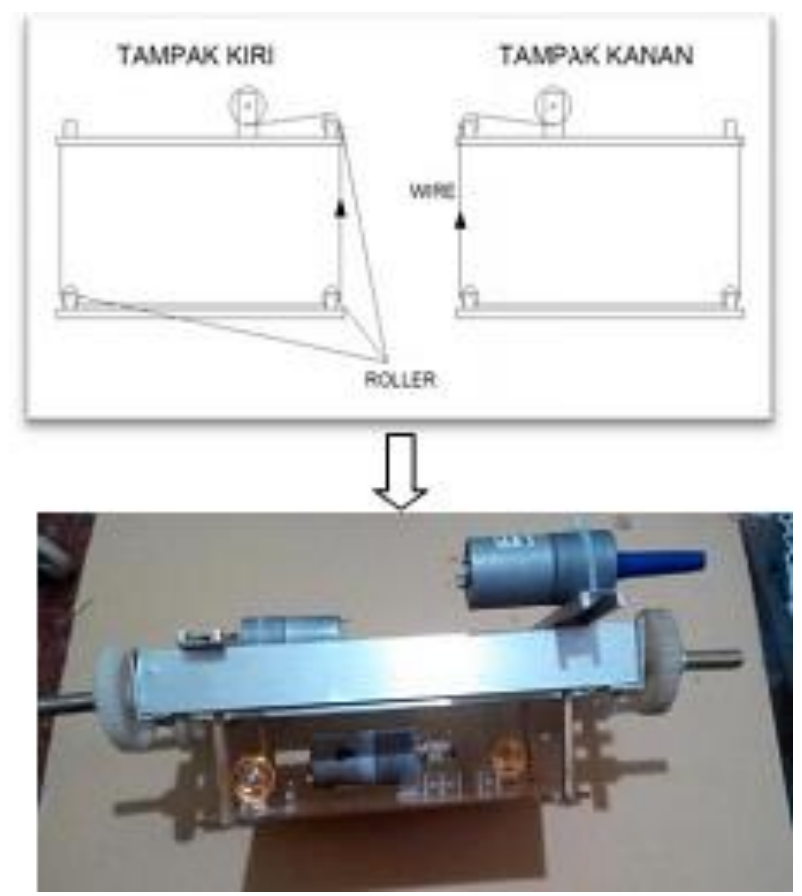

Figure. 3. Construction of Hoist Crane

When grip process, mini servo motor which connected with spin-able lock has been activate to locking each container corner. The container grip process is shown in Figure 4 and Figure 5.

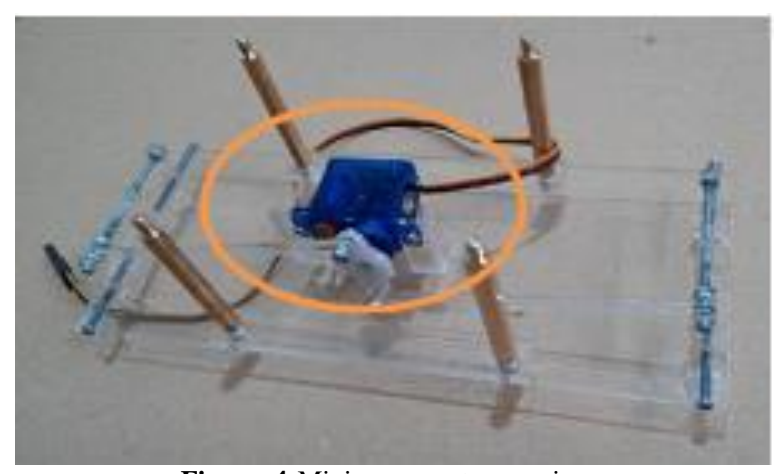

Figure. 4 Mini servo motor as gripper
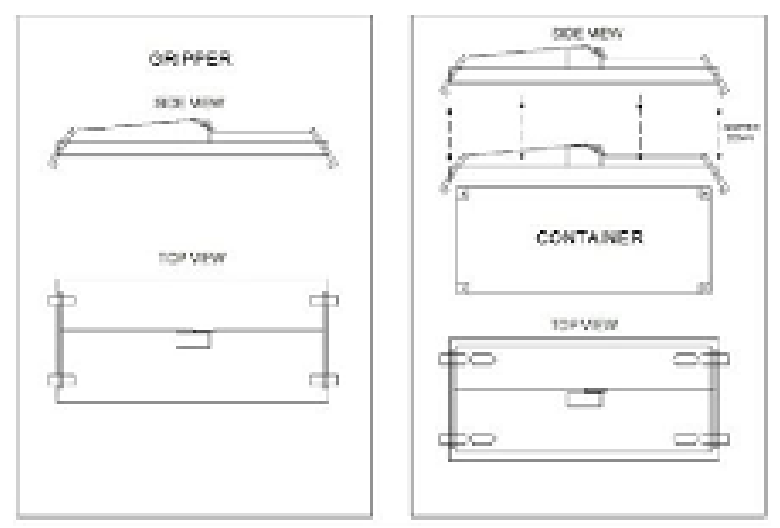

Figure. 5 Construction crane gripper

\section{A.4. Create Program on Adruino Mega 2560}

Arduino is a minimum system board microcontroller which is open source characteristic. In the circuit board contained Arduino AVR microcontroller series ATMega 328 which is a product of Atmel.

Arduino Mega 2560 is a microcontroller board ATmega 2560 by (datasheet) has 54 digital input / output pins (of which 15 can be used as PWM outputs), 16 analog inputs, 4 UARTs (hardware serial ports), a crystal oscillator $16 \mathrm{MHz}$, USB, jack electricity, ICSP header, and a reset button. It contains everything needed to support the microcontroller, simply connect it to a computer with a USB cable or poitr the AC-DC adapter or battery. Block diagram of system is shown in Figure 6. Wiring diagram input-output modul is shown in Figure 7. Wiring I/O Pin on Microcontroller is shown in Table 1 and Table 2. 


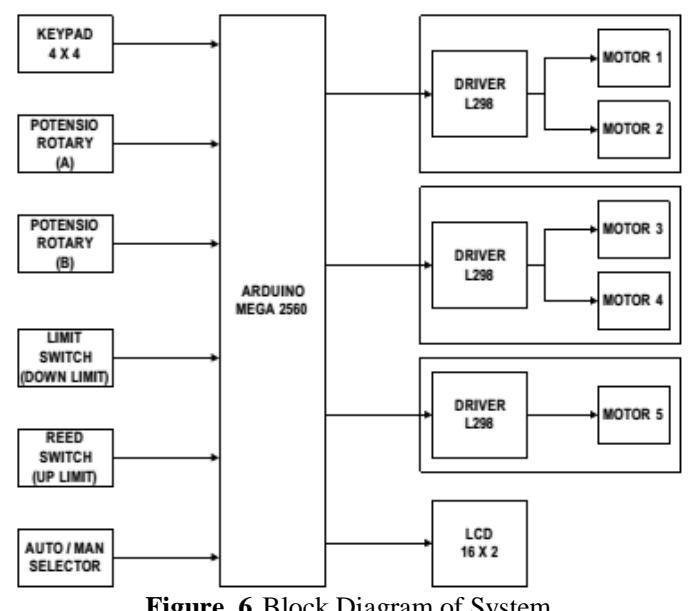

Figure. 6 Block Diagram of System

Descriptions of the motors used on the instrument are:

a. Motor $1=$ DC geared motor trolley

b. Motor 2 = DC geared motor trolley

c. Motor 3 = DC geared motor forward - backward d. Motor 4 = DC geared motor forward - backward e. Motor 5 = DC geared motor Up / Down

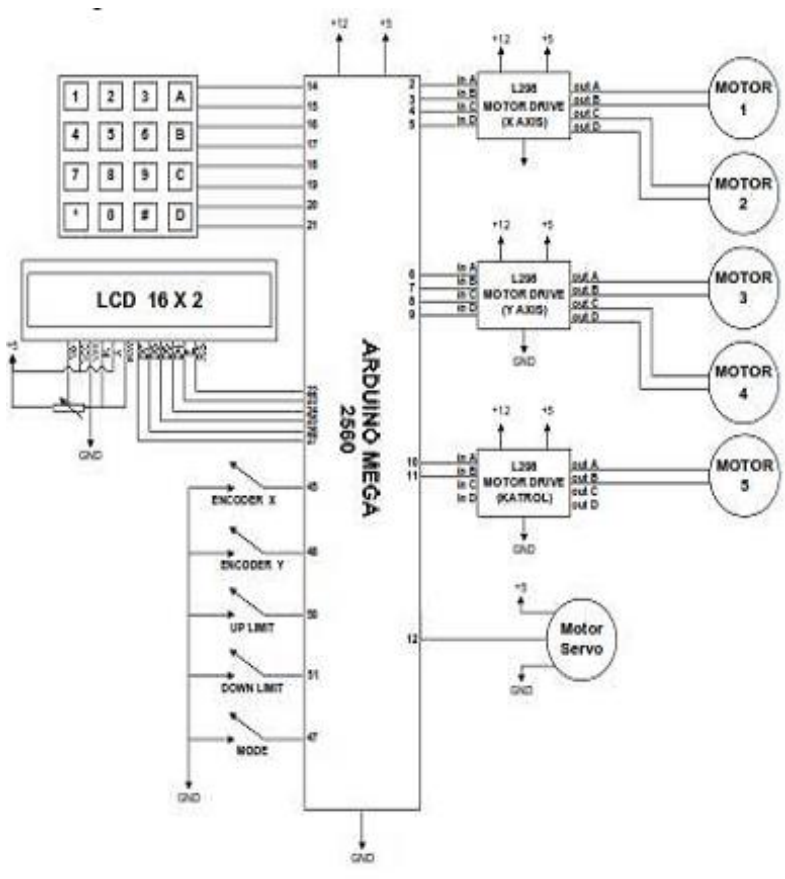

Figure. 7 Wiring Diagram Automatic Stacking Crane with Adruino

TABLE 1.

WIRING I/O PIN ON MICROCONTROLLER

\begin{tabular}{ccccc}
\hline No & Name & PIN & Input & Type \\
\hline & & \multicolumn{3}{c}{ Function } \\
\hline 1. & Selector & 47 & $\begin{array}{c}\text { Selection of Automatic / Manual } \\
\text { Reading input from axis X motor } \\
\text { rotation }\end{array}$ & $\begin{array}{c}\text { Potentiometer Rotary } \\
\text { Encoder X }\end{array}$ \\
3. & Encoder Y & 45 & Reading input from axis Y motor & Potentiometer Rotary \\
& & 46 & rotation & \\
4. & Down limit & 51 & Reading loitst position of gripper & Limit Switch \\
$\mathbf{5 .}$ & Up Limit & 50 & Reading highest position of & $\begin{array}{c}\text { Reed Switch } \\
\text { Keypad 4x4 }\end{array}$ \\
6. & Keypad 4x4 & $17,16,15,14-$ (rows) & Panel Input & \\
\hline
\end{tabular}


TABLE 2 .

WIRING I/O PIN ON MICROCONTROLLER MOTOR

\begin{tabular}{|c|c|c|c|c|}
\hline No & Name & PIN & Function & Type \\
\hline \multicolumn{5}{|c|}{ Output } \\
\hline 1. & $\begin{array}{l}\text { Servo } \\
\text { Gripper }\end{array}$ & $\begin{array}{c}12 \\
(\sim \mathrm{pwm})\end{array}$ & $\begin{array}{l}\text { Prime- } \\
\text { mover } \\
\text { actuator to } \\
\text { grip } \\
\text { container } \\
\text { corner }\end{array}$ & Servo Motor \\
\hline 2. & Motor 1a & $\begin{array}{c}2 \\
(\sim \mathrm{pwm})\end{array}$ & \multirow{2}{*}{$\begin{array}{l}\text { Prime- } \\
\text { mover of } \\
\text { axis X }\end{array}$} & $\begin{array}{c}\text { DC Gear } \\
\text { Motor 1:220 }\end{array}$ \\
\hline 3. & Motor $1 \mathrm{~b}$ & $\begin{array}{c}3 \\
(\sim \mathrm{pwm})\end{array}$ & & $\begin{array}{c}\text { DC Gear } \\
\text { Motor } 1: 220 \\
\end{array}$ \\
\hline 4. & Motor 2a & $\begin{array}{c}4 \\
(\sim \mathrm{pwm})\end{array}$ & \multirow{2}{*}{$\begin{array}{l}\text { Prime- } \\
\text { mover of } \\
\text { axis X }\end{array}$} & $\begin{array}{c}\text { DC Gear } \\
\text { Motor 1:220 }\end{array}$ \\
\hline 5. & Motor 2b & $\begin{array}{c}5 \\
(\sim \mathrm{pwm})\end{array}$ & & $\begin{array}{c}\text { DC Gear } \\
\text { Motor } 1: 220\end{array}$ \\
\hline 6. & Motor 3a & $\begin{array}{c}6 \\
(\sim \mathrm{pwm})\end{array}$ & \multirow{2}{*}{$\begin{array}{l}\text { Prime- } \\
\text { mover of } \\
\text { axis Y }\end{array}$} & $\begin{array}{c}\text { DC Gear } \\
\text { Motor } 1: 220\end{array}$ \\
\hline 7. & Motor 3b & $\begin{array}{c}7 \\
(\sim \mathrm{pwm}) \\
\end{array}$ & & $\begin{array}{c}\text { DC Gear } \\
\text { Motor } 1: 220 \\
\end{array}$ \\
\hline 8. & Motor 4a & $\begin{array}{c}8 \\
(\sim \mathrm{pwm})\end{array}$ & \multirow{2}{*}{$\begin{array}{l}\text { Prime- } \\
\text { mover of } \\
\text { axis Y }\end{array}$} & $\begin{array}{c}\text { DC Gear } \\
\text { Motor 1:220 }\end{array}$ \\
\hline 9. & Motor 4b & $\begin{array}{c}9 \\
(\sim \mathrm{pwm})\end{array}$ & & $\begin{array}{c}\text { DC Gear } \\
\text { Motor 1:220 }\end{array}$ \\
\hline 10. & Motor 5a & $\begin{array}{c}10 \\
(\sim \mathrm{pwm})\end{array}$ & \multirow{2}{*}{$\begin{array}{l}\text { Hang up } \\
\text { Gripper }\end{array}$} & $\begin{array}{c}\text { DC Gear } \\
\text { Motor } 1: 220\end{array}$ \\
\hline 11. & Motor 5b & $\begin{array}{c}11 \\
(\sim \mathrm{pwm})\end{array}$ & & $\begin{array}{c}\text { DC Gear } \\
\text { Motor } 1: 220 \\
\end{array}$ \\
\hline 12. & $\begin{array}{l}\text { LCD } 16 \\
\times 22\end{array}$ & $\begin{array}{l}22 \mathrm{rs} \\
23 \mathrm{e} \\
24 \mathrm{~d} 4 \\
25 \mathrm{~d} 5 \\
26 \mathrm{~d} 6 \\
27 \mathrm{~d} 7\end{array}$ & Display & $\begin{array}{l}\text { LCD } 16 \\
\times 2\end{array}$ \\
\hline
\end{tabular}

\section{B. Simulation Prototype}

In simulation stage, for determining prototype can run itll in accordance with the actual condition, some required components such as:

\section{B.1. Arduino Mega 2560}

As a central process in the entire system both read input and output the required by the user in accordance with a program that has been designed to move the miniature container at the position you want to jump.

\section{B.2. Motor Driver L298}

As an amplifier PWM input signal coming from Arduino mega 2560 to drive the motor. L298 motor driver applied to drive motors on the $\mathrm{X}$ axis, $\mathrm{Y}$-axis and pulley.

\section{B.3. Potensio Rotary}

As read the position of each crane movement on the $\mathrm{X}$ axis and $\mathrm{Y}$ axis rotary output than the pot in the form of pulses derived from the movement of the rotary pot shaft connected to the motor of the $\mathrm{X}$ axis and $\mathrm{Y}$ axis, each one round of the pot there are 20 pulses output which can be processed by the Arduino to its position.

\section{B.4. Limit switch}

As to read a loitr limit than the pulley with a rope pulley utilizing loads level.

\section{B.5. Reed switch}

Used for reading the upper limit rather than a pulley when there is contact with a magnet that is connected to the top of the pulley.

In the operation of the device there are two modes that can be used are: manual mode and auto mode, operating instructions manual of the device can be done when the position mode switch is in the manual position. There are ten locations of container placement position and is divided as follows: position A, B, C, D, E, F, G, H, I and J. Position A to I is a layout container that is at a location in the port terminal while the a position is a point of trucks that are in the process of loading / unloading. Here is a picture of the overall tool along with the location of the container position. For all system prototype is shown in Figure 8. Keypad buttons for simulation are shown in Table 3 . 


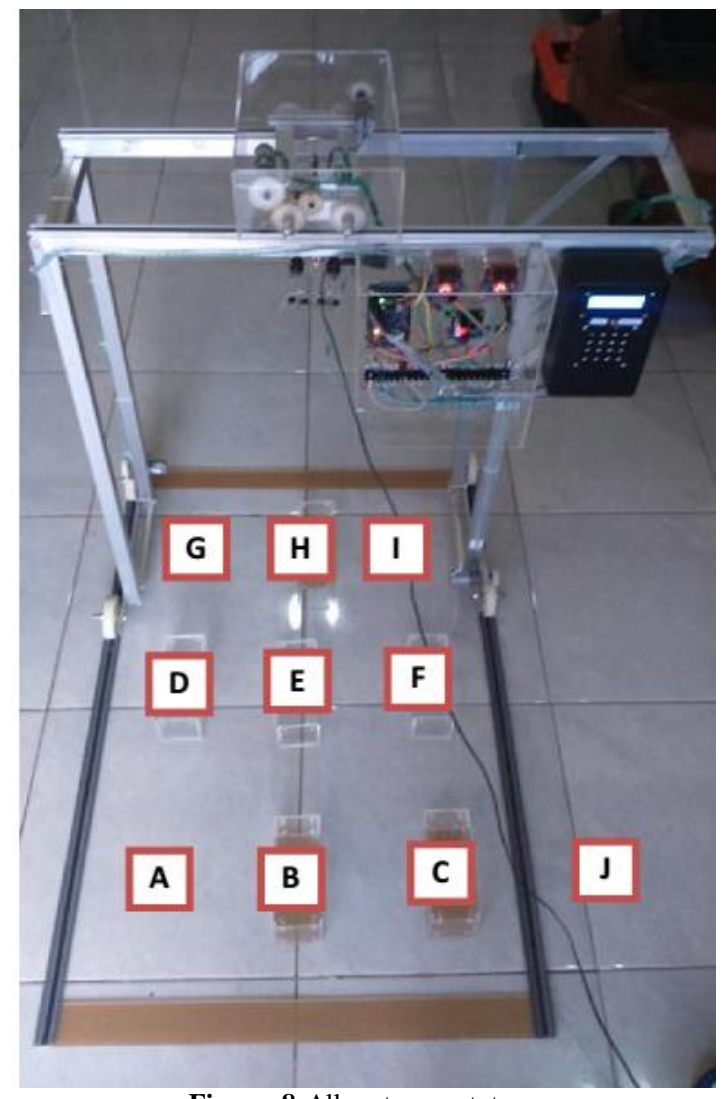

Figure. 8 All system prototype

TABLE 3.

(A). BUTTON NUMBER FUNCTION ON KEYPAD

\begin{tabular}{ccc}
\hline Button & Manual & Automatic \\
\hline 1. & Move to position A & Take Data A \\
2. & Move to position B & Take Data B \\
3. & Move to position C & Take Data C \\
4. & Move to position D & Take Data D \\
5. & Move to position E & Take Data E \\
6. & Move to position G & Take Data F \\
7. & Move to position H & Take Data G \\
8. & Move to position I & Take Data H \\
9. & Move to position J & Take Data I \\
0. & Gripper Up/Down J & - \\
$*$ & Gripper Lock / Unlock & - \\
$\#$ & &
\end{tabular}

(B). BUtTON ALPHABETIC FUNCTION ON KEYPAD

\begin{tabular}{ccc}
\hline Button & Manual & Automatic \\
\hline A & - & Start \\
B & & Stop \\
C & - & Save target position \\
D & - & Save destination target \\
\hline
\end{tabular}

\section{Simulation in Automatic Crane}

For moving the crane automatically is done by directing selector in automatic position and then input the data in advance. Rather than a system running workflow systematically and sequentially after the start button is pressed. Block diagram of Automatic Crane is shown in Figure 9.

To perform the target first input the user must fill in the target data by selecting a target position in accordance with the position $0-9$. then press the " $\mathrm{C}$ " to save the position of interest. Meanwhile, to make the destination input the user can choose the position by pressing the numbers $0-9$ and press the " $\mathrm{D}$ " to save the target position. After filling the position of the target and dining destination users can start the procedure by pressing the "A". Button on automatic mode are described in Figure 10 and Figure 11 


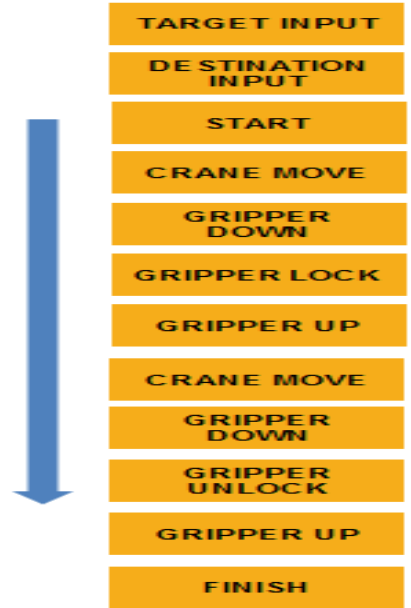

Figure. 9 Blok Diagram of Automatic Mode

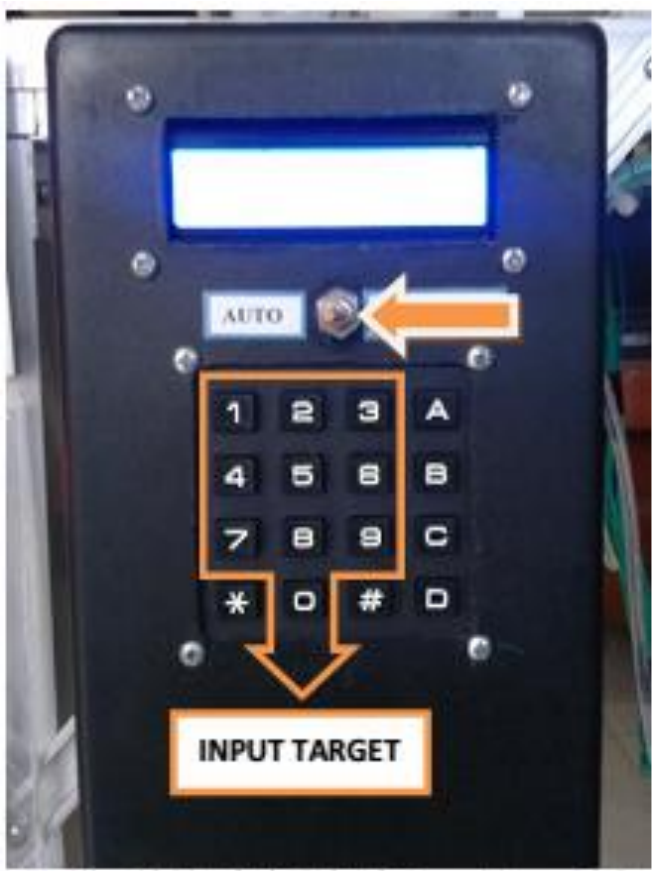

Figure. 10 Input button in automatic mode

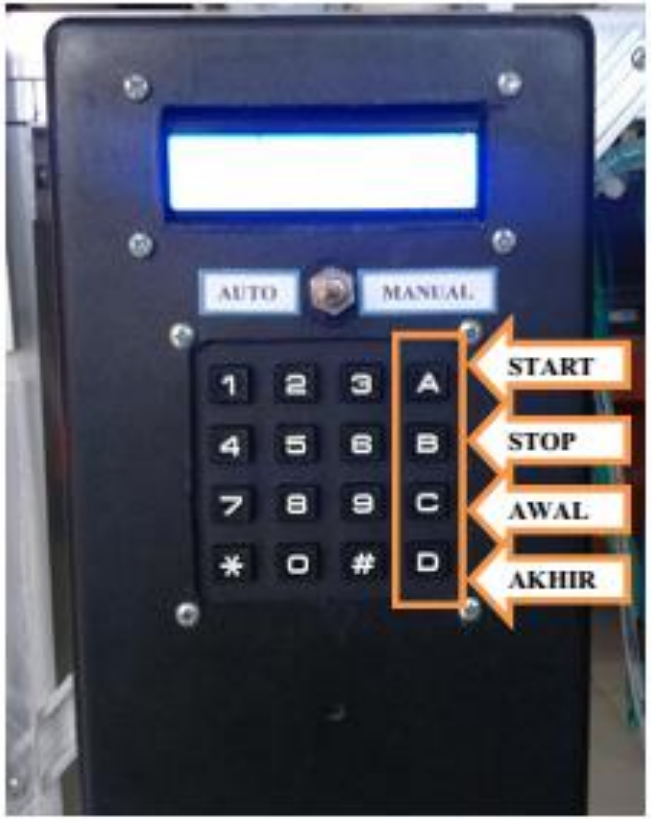

Figure. 11 Start, stop, begin, and end button 
From the simulation results obtained speed of the tool in the process of moving container is shown in Table 4.

TABLE 4 . OPERATION SPEED OF MOTOR

\begin{tabular}{|c|c|c|}
\hline No & Name & Speed \\
\hline 1. & Trolley Motor & $3,99 \mathrm{~m} / \mathrm{mm}$ \\
\hline 2. & Gripper Up (Load) & $1,56 \mathrm{~m} / \mathrm{mm}$ \\
\hline 3. & Gripper Down (Load) & $1,56 \mathrm{~m} / \mathrm{mm}$ \\
\hline 4. & Gripper Up (Unload) & $1,74 \mathrm{~m} / \mathrm{mm}$ \\
\hline 5. & Gripper Down (Unload) & $2,28 \mathrm{~m} / \mathrm{mm}$ \\
\hline 6. & Gripper Fore-Back & $3,03 \mathrm{~m} / \mathrm{mm}$ \\
\hline 7. & Grip (Lock / Unlock) & $2 \mathrm{~s}$ \\
\hline
\end{tabular}

\section{CONCLUSION}

Based on the analysis and simulation of Automatic Stacking Crane with Adruino, it can be concluded as follows:

a. Design of prototype automatic stacking crane by using microcontroller such as Arduino can work itll in accordance with a design that has been designed.

b. When given the command and do manual initialization gripper movements fairly stable although there was a little shock because of its mechanical design are less than perfect.

c. The incoming voltage to the motor sourced from Arduino that is $5 \mathrm{v}$, so that the spindle motor is not optimal. In addition, there are still many input response procedure was not appropriate.

d. Laying cables on the gripper and trolley wires to laying a good mechanism necessary in order not to interfere with the movement of the trolley and the gripper on the work process of the tool.

e. From the test results obtained speed of the tool in the process of moving a container with trolley motor speed $3,99 \mathrm{~m} / \mathrm{min}$, up gripper motor speed (load) $1.56 \mathrm{~m} \mathrm{/} \mathrm{min,} \mathrm{up} \mathrm{gripper} \mathrm{motor}$ speed (unloaded) to $1.74 \mathrm{~m} / \mathrm{min}$, gripper motor speed down (load) $1.56 \mathrm{~m} / \mathrm{min}$, down gripper motor speed (unloaded) $2.28 \mathrm{~m} / \mathrm{min}$, the motor speed gripper back and forth to $3.03 \mathrm{~m} / \mathrm{min}$, Grip (Lock / Unlock) 2 seconds

\section{REFERENCES}

[1] Nuzula, Arma,"Analisa Modernisasi Sistem Otomasi Pada Container Crane Dengan Menggunakan PLC Siemens" Jurusan Sistem Perkapalan FTK-ITS, Surabaya 2015.

[2] Malvino, Albert P,'Prinsip-Prinsip Elektronika Edisi Ketiga Jilid 2", Penerbit Erlangga, Jakarta, 1996.

[3] Rashid, "Power Electronic Circuit, Device, and Applications", 3rd Ed., Prentice Hall, 2004

[4] Kaunang, Jason.'Perangkat Transmisi Otomatis Pada Motor Berbasis Mikrokontroller", Jurusan Teknik Elektro Universitas Widya Kartika, Surabaya 2015 